\title{
Assessment of photovoltaic generation, supply, and sustainability: a case study of municipalities in São Paulo state
}

\author{
Análise de potencial de geração e suprimento fotovoltaicos \\ e sustentabilidade: estudo de caso de municípios do \\ estado de São Paulo
}

Nilo Amaral Martin ${ }^{a}$

Antônio Cesar Germano Martins ${ }^{b}$

${ }^{a}$ MSc in Biometry, PhD student, Instituto de Ciência e Tecnologia de Sorocaba - ICTS, Universidade Estadual Paulista Júlio de Mesquita Filho - UNESP, Sorocaba, SP, Brazil E-mail: niloamartin@gmail.com

${ }^{b}$ PhD in electrical engineering, professor at Instituto de Ciência e Tecnologia de Sorocaba - ICTS, Instituto de Ciência e Tecnologia de Sorocaba- ICTS, Universidade Estadual Paulista Júlio de Mesquita Filho - UNESP, Sorocaba, SP, Brazil E-mail:antonio.martins@unesp.br

doi:10.18472/SustDeb.v12n2.2021.37015

Received: 23/03/2021

Accepted: 28/06/2021

ARTICLE - VARIA

\begin{abstract}
Energy consumption has been increasing together with population growth and the consequences for energy production widely generate discussions under the aspect of environmental outcome and supply reliability and quality. This paper proposes a methodology that allows the estimation of the potential for cities to be more independent in terms of centralized generation and distribution of electricity considering photovoltaic sources. Sustainability and environmental performance are also discussed. The methodology aims to assess some municipalities in the São Paulo state. The results showed high potential for photovoltaic supply in those municipalities under the considered conditions indicating the possibility for structuring a decentralized generation model where cities would be more independent in electricity supply. Implementing the required photovoltaic systems would return the energy consumed during their life cycle in a relatively short period compared to their expected lifetime.
\end{abstract}

Keywords: Sustainable energy. Photovoltaic generation. Sustainability. Distributed generation. Modelling.

\section{RESUMO}

O consumo de energia tem aumentado com o crescimento populacional, e os impactos causados em função da geração de energia vêm sendo discutidos sob o ponto de vista de suas consequências ambientais, bem como a qualidade e a confiabilidade no fornecimento. Este trabalho tem como objetivo desenvolver uma metodologia que permita a análise da viabilidade de uma maior independência das 
cidades em relação à geração centralizada, por meio do estudo do potencial de geração distribuída e suprimento do consumo de energia elétrica pela fonte fotovoltaica. A sustentabilidade e a performance ambiental também são abordadas. São avaliadas algumas cidades do interior de São Paulo e os resultados mostram que há grande potencial de suprimento fotovoltaico sob determinadas condições, indicando a possibilidade de uma maior independência da geração centralizada. Observou-se que os sistemas fotovoltaicos necessários retornariam a energia consumida em seu ciclo de vida em um período de tempo relativamente pequeno.

Palavras-chave: Energiasustentável. Geraçãofotovoltaica. Sustentabilidade. Geração distribuída. Modelagem.

\section{INTRODUCTION}

In 2018, global economic growth of $3.7 \%$ was observed in comparison with 2017, resulting in a $2.3 \%$ increase in energy demand and a $1.7 \%$ increase in carbon dioxide $\left(\mathrm{CO}_{2}\right)$ emissions, associated with the use of fossil fuels as a primary energy source (IEA, 2018, p. 4). To reduce the impacts of fossil fuel energy generation caused by gas emissions, renewable and sustainable sources have been widely considered to decrease environmental consequences. Those sources represented $26 \%$ of all electricity generated worldwide in 2018 when increases in the installed capacity of renewable energy were higher than increases in the installed capacity of fossil and nuclear fuels for the fourth year in a row (REN21, 2019, p. 29).

In the Brazilian scenario, $64.08 \%$ of the electric energy matrix comes from hydro-power plants, $25.40 \%$ from thermoelectric plants, $9.06 \%$ from wind generators, and $1.46 \%$ from photovoltaic (PV) solar panels (BIG, 2019). Those numbers show that, besides using hydroelectric power plants, other renewable sources are also being used.

Brazil has a great PV generation potential due to its geographic localization and climatic characteristics, and an increase in PV power generation has been noticed in the last few years. In 2018, Brazilian PV energy generation was approximately 298 thousand toe ${ }^{1}$, while in 2017 it was approximately 72 thousand toe, representing an increase of 316.2\% (BRASIL, 2019, p. 19).

This work proposes a methodology that allows the estimation of the potential for cities to be more independent in terms of centralized generation and distribution of electricity considering photovoltaic sources. The analysis is performed considering the electric power generation and potential supply of PV energy at the municipal level, to decrease the dependency on the centralized generation. The methodology also takes into account the sun's daily path, the available roof area, and different orientations of the PV module, to simulate residential roof installation.

The calculation of PV potential takes into account a hierarchical methodology that considers the following three levels: physical potential, geographical potential, and technical potential (IZQUIERDO; RODRIGUES; FUEYO, 2008, p. 931). The physical potential is the total energy from the Sun that reaches the studied area; geographical potential consists of the locations where the energy will be captured - residential rooftops, and the technical potential include the technical features of energy conversion equipment for electricity generation and PV module orientation. This approach is addressed in the studies by Assouline, Mohajeri and Scartezzini (2017), Martín, Domínguez and Amador (2015), Nero et al. (2020) and Sun et al. (2013).The next section gives detailed definitions of the parameters and how they are used for analysis. 


\section{METHODOLOGY}

PV generation depends directly on solar radiation, that is, the amount of incident energy per unit area of a surface (KALOGIROU, 2014, p. 20). This data has been considered as the physical potential for PV generation and is made available by some institutional websites, such as the websites from the National Institute of Meteorology (INMET) and the National Institute for Space Research (Inpe), through the Sistema de National Environmental Database System (Sonda), the Reference Center for Solar and Wind Energy Sergio de S. Brito (Crecesb), and the Inpe's Brazilian Atlas of Solar Energy - see Pereira et al. (2017). These data come from automatic measurement stations, which include mainly data from environmental parameters, as well as data generated through mathematical models, for several locations in Brazil. The websites can be accessed through the Crecesb (2020), Inmet (2019), and Inpe (2019).

Pereira et al. (2017, p. 35) provided data from statistical models obtained from analysis of the Brazilian solar radiation temporal series made available by the Inmet (2019) and Inpe (2019). Solar radiation estimates are made available by the Crecesb (2020) in a database that was built using satellite imagery and data from a period of 17 years (PEREIRA et al., 2017).

PV generation potential can be evaluated through the following other parameters, besides solar radiation:

- PV module orientation, which is part of the technical potential for PV generation, depends on the surface tilt angle $(\beta)$ and the angle between the normal to the module's surface in the horizontal plane and the true North, known as Surface Azimuth Angle $\left(Z_{s}\right)$ (KALOGIROU, 2014, p. 63);

- the Sun's daily path during the day, according to the location coordinates of interest (KALOGIROU, 2014, p. 60);

- total available area for PV module installation and the efficiency of PV conversion, which been considered as the geographical potential for PV generation.

The parameters for estimating PV generation and supply, as well as the methodology used, will be defined as follows.

\subsection{MODULE ORIENTATION}

The PV module orientation is evaluated according to the surface tilt angle $(\beta)$ and the angle between the normal to the module's surface in the horizontal plane and the true North, known as Surface Azimuth Angle ( $z_{s}$ ) (KALOGIROU, 2014, p. 63). The surface tilt angle $(\beta)$ has its origin in the horizontal plane containing the module and is illustrated in Figure 1(a).

In the present study, it will be assumed to have the same latitude value from the place of interest, taking into account that this would be the optimum tilt angle for achieving the highest mean solar radiation along the year (TOLMASQUIM, 2016, p. 326).

The Surface Azimuth Angle $\left(Z_{s}\right)$ describes the module rotation around the horizontal plane normal direction. The angle is formed by the normal to the module's surface in the horizontal plane and the true North, which is considered as the origin. Westwards is designated as the positive direction. The parameters are shown in Figure 1(a). 


\subsection{SUN'S DAILY PATH}

The Sun's daily path was modelled according to the parameters mentioned as follows in a threedimensional representation. Those parameters are angles $-\mathbf{a}$ and $\mathbf{Z}-$, which have been adapted to the spherical system of coordinates (STEWART, 2015, p. 927) and are shown in Figure 1(b).

The $\alpha$ angle, defined as the solar altitude angle, is given by (KALOGIROU, 2014, p. 60)

$$
\sin (a)=\sin (L) \sin (\delta)+\cos (L) \cos (\delta) \cos (h)
$$

where:

- L s the latitude, with locations in the Northern hemisphere considered as positive values and those in the Southern hemisphere considered as negative values;

- $\delta$ is the solar declination, defined as the angle between the equatorial and ecliptic planes. The ecliptic plane is the one containing Earth in its orbit;

- $h$ is the hour angle, defined as the angle that Earth would have to turn for its centre (point 0 ), the location of interest (point P), and the centre of the sun to be contained in a unique plan in a given day hour, as shown in Figure 1(c). The same figure also shows the $L, \delta$ and h parameters, which are functions of latitude, longitude, and time of the year, being related to solar declination $(\delta)$ (KALOGIROU, 2014, p. 56).

(a)

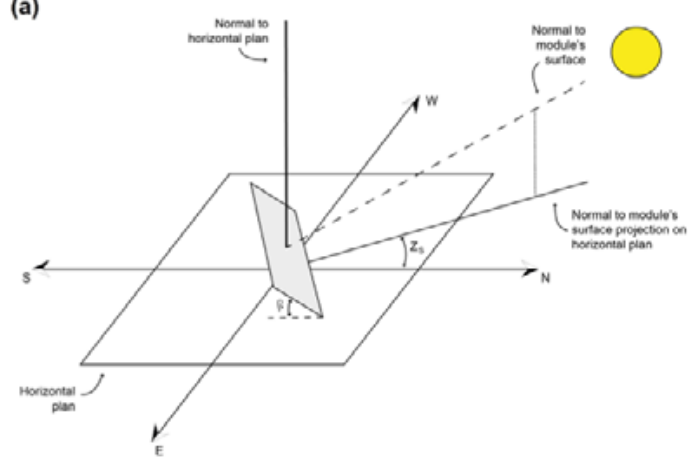

(b)

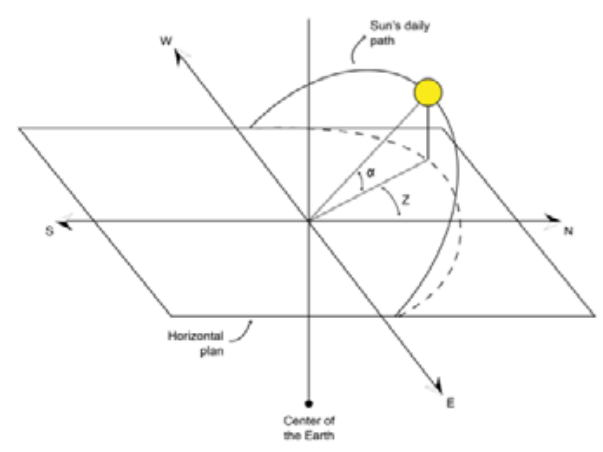

(c)

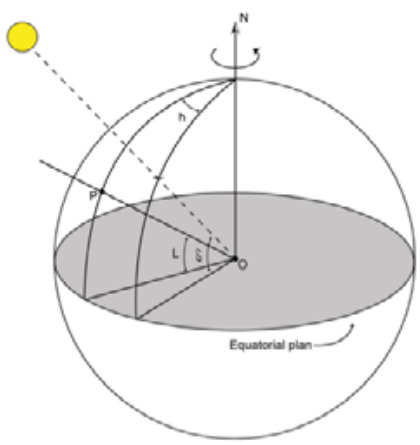

Figure 1 | (a) Parameters $\beta$ and, $Z_{s}$ tilt and azimuth surface angles, respectively. (b) Angles $\alpha$ and $Z$, which describes the Sun's daily path. (c) Solar parameters $L, \delta$ and h.

Source: Own elaboration, based on Kalogirou (2014, p. 60). 
Solar declination $(\delta)$ ranges according to the relative position of the Earth to the Sun. Thus, it ranges according to the period of the year. According to (KALOGIROU, 2014, p. 60):

$$
\delta=23.45 \sin \left[\frac{360}{365}(284+N)\right]
$$

where $\mathrm{N}$ is the Julian day of the year.

In this study, the PV potential has been obtained for each month of the year using the average day length in a month, as shown in Table 1.

Solar altitude angle $(\mathrm{a})$ is a function of the hour angle $(\mathrm{h})$, which ranges according to the local standard time - the local clock time. The hour angle for a certain location is given by (KALOGIROU, 2014, p. 59)

$$
\mathrm{h}=15(\mathrm{AST}-12)
$$

where AST is the apparent solar time, based on the Sun's angular motion in the sky. The solar noon occurs when the Sun crosses the observer's meridian. The parameter $\mathrm{h}$ is negative for morning hours, positive for afternoon hours and is zero at the solar noon, when AST $=12$.

\begin{tabular}{|c|c|c|}
\hline \multirow{2}{*}{ Month } & \multicolumn{2}{|c|}{ Average day } \\
\hline & Date & Number \\
\hline January & 17 & 17 \\
\hline February & 16 & 47 \\
\hline March & 16 & 75 \\
\hline April & 15 & 105 \\
\hline May & 15 & 135 \\
\hline June & 11 & 162 \\
\hline July & 17 & 198 \\
\hline August & 16 & 228 \\
\hline September & 15 & 258 \\
\hline October & 15 & 288 \\
\hline November & 14 & 318 \\
\hline December & 10 & 344 \\
\hline
\end{tabular}

Table 1 | Average Julian day, with respective date and number.

Source: Data from Kalogirou (2014, p. 58).

AST is based on other factors, including local standard time, according to the equation (KALOGIROU, 2014, p. 53)

$$
\mathrm{AST}=\mathrm{LST}+\mathrm{ET} \pm 4[\mathrm{SL}+\mathrm{LL}]
$$


where

- LST is the local standard time, that is, the local clock time;

ET is the equation of time;

- SL is the standard longitude, that is, the longitude of the local timezone;

- LL is the local longitude.

The sign of the third member of the equation is negative (-) if the location is West of Greenwich and positive (+) if otherwise (KALOGIROU, 2014, p. 53).

Therefore AST and h change according to LST. The values of LST of the municipalities studied were obtained using the respective sunrise times $\left(h_{S R}\right)$, sunset times $\left(h_{S S}\right)$ and day length ( $\left.D L\right)$ according to the following expressions (KALOGIROU, 2014, p. 61)

$$
\begin{gathered}
\cos \left(h_{\mathrm{SR}}\right)=\tan (\mathrm{L}) \tan (\delta) \\
\mathrm{DL}=\frac{2}{15} \cos ^{-1}[-\tan (\mathrm{L}) \tan (\delta)]
\end{gathered}
$$

and

$$
\cos \left(h_{S S}\right)=h_{S R}+D L
$$

The apparent solar time (AST) is also influenced by the equation of time (ET), as shown in equation (4), which considers the natural variation of the 24-hour mean day length. Thus, ET is a correction factor, given in minutes, for the day length of day throughout the year, given by

$$
E T=9.87 \sin (2 B)-7.53 \cos (2 B)-1.5 \sin (B)
$$

where $\mathrm{B}$ depends on the Julian day of the year $(\mathrm{N})$ :

$$
B=(N-81) \frac{360}{364}
$$

With the parameters $h_{S R}, h_{S S}$ and $D L, L S T, A S T$ and $h$ values for each minute in the days, sunlight periods can be calculated and with equation (1) the values of solar altitude angle ( a ) for each minute of the average days can be obtained for a given municipality. 
The solar azimuth angle ( $Z$ ), the second parameter that defines the Sun's daily path shown in Figure $1(b)$, has its origin in the true North with positive values westwards, being obtained using (KALOGIROU, 2014, p. 60):

$$
\sin (Z)=\frac{\cos (\delta) \sin (h)}{\cos (a)}
$$

provided that

$$
\cos (h)>\frac{\tan (\delta)}{\tan (L)}
$$

Otherwise, the Sun is in the East-West plane in true South and

$$
Z=-\pi+|Z|
$$

for morning hours $(\mathrm{h}<0)$ and

$$
Z=Z-\pi
$$

for afternoon hours $(\mathrm{h}>0)$.

\subsection{AVAILABLE AREA AND CONVERSION EFFICIENCY}

In the present study, the available area for PV module installation has been considered as the estimated roof area of the location of interest. The estimation process is described in this section.

The roof area was estimated through digital image processing (DIP) using Matlab (MATLAB, 2010), and the image samples were obtained from Google Earth Pro. Figure 2 shows one of the images used, on the left, and the result of the segmentation process on the right.

The images were acquired maintaining the original parameters of image resolution, tilt, and viewpoint's distance, with an image resolution of $4800 \times 2220$ pixels and viewpoint's distance equal to $1 \mathrm{~km}$. The tilt parameter was reset before each acquisition. The spatial resolution of the images is $25 \mathrm{~cm}$. 

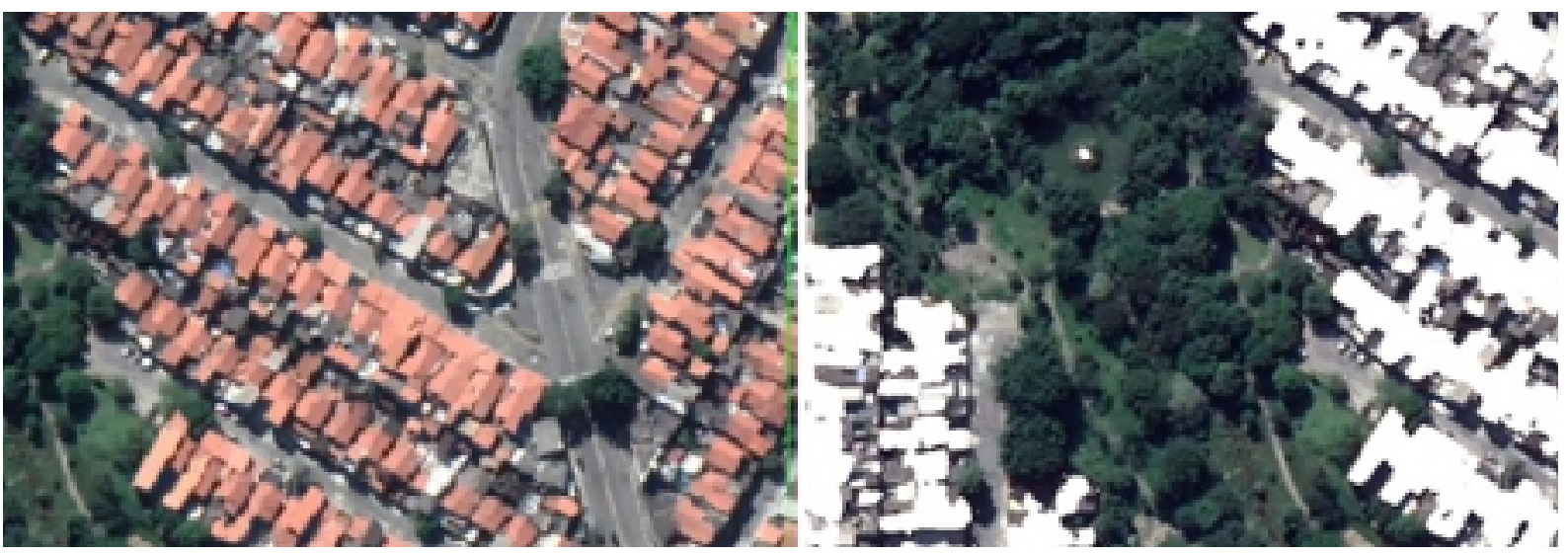

Figure 2 | Example of image sample example on the left, used in roof area estimates, and the result of segmentation on the right.

Source: Own elaboration. Collected via Google Earth Pro.

For each municipality studied, image samples of representative urban areas were selected and the roof area was estimated using pixel segmentation, based on the usual orange colouring on the roofs. The representative areas were selected by visual analysis of each municipality, considering the land cover distribution in different sectors. The ratio between the number of pixels of the segmented and the total image was obtained from the proportion of the roof area.

Thus, for each municipality $\mathrm{k}$, a sample of size $\mathrm{n}$ was collected and the proportion of the roof area for each one of the $n$ sample images was obtained with the following expression:

where

$$
\mathrm{T}_{\mathrm{i}}^{\mathrm{k}}=\frac{\mathrm{N}_{\mathrm{seg}}^{\mathrm{i}}}{\mathrm{N}_{\text {total }}^{\mathrm{i}}}, \quad \text { with } \mathrm{i}=1,2, \cdots, \mathrm{n}
$$

- $\mathrm{T}_{\mathrm{i}}^{\mathrm{k}}$ is the roof proportion in pixels in image i of the municipality $\mathrm{k}$;

$\mathrm{N}_{\text {seg }}^{\mathrm{i}}$ is the number of segmented pixels in image $\mathrm{i}$;

$\mathrm{N}_{\text {total }}^{\mathrm{i}}$ is the total number of pixels in image $\mathrm{i}$;

- $\mathbf{k}$ is the city index, ranging from 1 to 16 in the present study;

$\mathrm{n}$ is the number of different image samples for the municipality $\mathrm{k}$.

The mean of the $\mathrm{n}$ proportions was calculated for each municipality $\mathrm{k}$ as follows:

$$
\overline{\mathrm{T}}^{\mathrm{k}}=\frac{1}{\mathrm{n}} \sum_{\mathrm{i}=1}^{\mathrm{n}} \mathrm{T}_{\mathrm{i}}^{\mathrm{k}}, \quad \text { with } \mathrm{k}=1, \cdots, 16
$$


Then, the estimation of roof area for each municipality $k$ was calculated by multiplying the mean proportion of segmented roof pixels and the urban areas obtained from IBGE (2020):

$$
\mathrm{AT}^{\mathrm{k}}=\overline{\mathrm{T}}^{\mathrm{k}} \times \mathrm{A}_{\mathrm{urb}}^{\mathrm{k}}, \quad \text { with } \mathrm{k}=1,2, \cdots, 16
$$

where

- $A \mathrm{~T}^{\mathrm{k}}$ is the estimated roof area for municipality k, given in $\mathrm{km}^{2}$;

- $A_{u r b}^{k}$ is the urban area for municipality k, given in $\mathrm{km}^{2}$.

\subsection{PHOTOVOLTAIC GENERATION AND SUPPLY POTENTIAL}

Through the information described in the previous sections, it was possible to estimate the PV generation and energy supply potential of the municipality, which are considered indicators of the capacity for being independent of centralized electricity generation.

Taking into account the $15 \%$ efficiency ${ }^{2}$ (TOLMASQUIM, 2016, p. 340), the mean monthly solar radiation in 2017 and the roof areas obtained, the estimation of the PV generation potential $\left(F_{m}^{k}\right)$ for each

municipality $\mathrm{k}$ in the month $\mathrm{m}$ was obtained through the following expression:

$$
\mathrm{F}_{\mathrm{m}}^{\mathrm{k}}=\mathrm{I}_{\mathrm{m}}^{\mathrm{k}} \times \mathrm{AT}^{\mathrm{k}} \times 10^{6} \times 0.17 \times \mathrm{H}_{\mathrm{m}}^{\mathrm{k}} \quad \text { with } \mathrm{m}=1, \cdots, 12 \mathrm{e} \mathrm{k}=1, \cdots, 16
$$

where

- $I_{m}^{k}$ is the mean monthly solar radiation, given in $\mathrm{kWh} / \mathrm{m}^{2}$ for the municipality $\mathrm{k}$ obtained by the mean daily solar radiation per month, given in $\mathrm{kWh} / \mathrm{m}^{2}$.day, multiplied by the number of days for month $\mathrm{m}$;

- $A T^{k}$ is the estimated roof area for municipality $\mathrm{k}$, given in $\mathrm{km}^{2}$;

- 106 is the conversion factor from $\mathrm{km}^{2}$ to $\mathrm{m}^{2}$;

- 0.15 is the PV energy conversion factor;

- $H_{m}^{k}$ is the average direct solar incidence factor in the panels for municipality $k$ in month $m$, assuming values between 0 and 1 .

The mean direct solar incidence factor in the panels $\left(\mathrm{H}_{\mathrm{m}}^{\mathrm{k}}\right)$ is the mean percentage of the perpendicular incident radiation of the solar flux in the PV module surface, obtained minute by minute from the daily mean of each month, obtained from the relative position of the Sun position vector and the vector normal to the module's surface.

To assess these vectors, the parameters of the Sun's daily path and module's orientation were adapted to the system of spherical coordinates. In this three-dimensional system, each point and vector are defined through the parameters $\rho, \theta$ and $\varphi$ (STEWART, 2015, p. 927). 
The normal to the PV module surface vector $\vec{h}$ was represented with 4 assuming $Z_{S}$ values, and $\varphi$ assuming $\beta$ values, and the Sun's daily path vector $\vec{s}$ was represented with $\theta$ assuming $Z$ values, and $\varphi$ assuming $90-a$ values. Both vectors are unitary since the focus is their direction:

$$
\overrightarrow{\mathrm{n}}=\left(1, Z_{S}, \beta\right)
$$

and

$$
\overrightarrow{\mathrm{s}}=(1, Z, 90-\alpha) \text {. }
$$

$\mathrm{H}_{\mathrm{m}}^{\mathrm{k}}$ for each month was obtained through the vector projection of $\vec{s}$ on $\vec{h}$, which was obtained with the scalar product between $\vec{s}$ and $\vec{n}$ that indicates the projection length (WINTERLE, 2014, p. 61).

The vector $\boldsymbol{n}$ was obtained with the surface azimuth angle $\left(Z_{S}\right)$ assuming values in the sequence $\{0,15, \ldots, 360\} \quad$ (see section 2.1). Therefore, $\boldsymbol{h}$ was obtained in 25 distinct positions, broadly allowing to model orientation.

With a fixed position of $\vec{n}$ for each $Z_{s}$ value, the vector $\vec{s}$, whose coordinates range with the hour angle ( $\mathbf{h}$ ), dependent on the local standard time ( L ST ), had its positions calculated minute by minute for each average day length in a month with the equations (5), (6), and (7) and then the vector projection modules of $\vec{s}$ on $\vec{n}$ were obtained.

Factor $\mathrm{H}_{\mathrm{m}}^{\mathrm{k}}$ was finally obtained by the mean of the vector projection $\vec{s}$ on $\vec{n}$ for each $\mathrm{Z}_{\text {s value along }}$ each average day length in a month, with $\vec{s}$ changing minute by minute. The index $m=1,2, \ldots, n$ indicates the month for which the factor was obtained.

Therefore, $H_{m}^{k}$ is given as follows:

$$
\mathrm{H}_{\mathrm{m}}^{\mathrm{k}}=\frac{1}{25} \sum_{\mathrm{i}=1}^{25}\left\{\frac{1}{\mathrm{t}} \sum_{\mathrm{j}=1}^{\mathrm{t}}\left|\overrightarrow{\mathrm{n}}_{\mathrm{i}} \cdot \overrightarrow{\mathrm{s}}_{\mathrm{j}}\right|\right\}
$$

where

- $\mathbf{i}$ index is related to the elements of the $Z_{S}$ values in sequence $\{0,15, \ldots, 360\}$;

- $\mathrm{j}$ is the month $\mathrm{m}$ average day length;

- $\left|\vec{n}_{i} \cdot \vec{s}_{j}\right|$ is the modulus of the scalar product between $\vec{n}_{i}$ and $\overrightarrow{\mathrm{s}}_{j}$.

When the angle between $\vec{s}$ and $\vec{h}$ was greater than $90^{\circ}, \mathrm{H}_{\mathrm{m}}^{\mathrm{k}}$ was considered as zero because it means that the direction of $\vec{s}$ is parallel or incident behind the PV module surface. 
The monthly and yearly estimations of PV energy supply contribution for each municipality were also obtained. The monthly estimation in percentage $\left(E_{m}^{k}\right)$ for month $m$ in municipality $k$ was obtained as follows:

where

$$
E_{m}^{k}=\frac{100 \times F_{m}^{k}}{C_{m}^{k}}
$$

- $F_{m}^{k}$ is the PV generation estimate for municipality k, from equation (14), given in kWh;

- $C_{m}^{k}$ is the average monthly energy consumption in sunlight periods for month $m$ in municipality $k$, given in $\mathrm{kWh}$.

In the present study, energy storage systems were not taken into account, so the PV energy generation potential was measured in sunshine periods. This is reflected by parameter, that is the average consumption in sunlight periods, given by

$$
C_{m}^{k}=Q_{m}^{k} \times K_{m}^{k}
$$

where

- $\mathrm{K}_{\mathrm{m}}^{\mathrm{k}}$ is the average consumption rate in sunlight periods for municipality $\mathrm{k}$, in month $\mathrm{m}$, given in $\mathrm{kWh}$, between 0 and 1 ;

$-Q_{m}^{k}$ is the mean consumption for municipality $k$, in month $m$, given in $k W h$.

The mean monthly consumption ( $Q_{m}^{k}$ ) was obtained from the annual consumption of each municipality, in São Paulo (2018, p. 23), with the expression below:

$$
\mathrm{Q}_{\mathrm{m}}^{\mathrm{k}}=\frac{\mathrm{C}_{\text {year }}^{\mathrm{k}} \times \mathrm{N}_{\mathrm{m}}}{365}
$$

where

- $\mathrm{N}_{\mathrm{m}}$ is the number of days for month $\mathrm{m}$;

- $\mathrm{N}_{\mathrm{m}} / 365$ is the month $\mathrm{m}$ proportion of the number of days.

The average consumption rate in sunlight periods $\left(\mathrm{K}_{\mathrm{m}}^{\mathrm{k}}\right)$ was obtained for each municipality, month by month, using the characteristic curve of residential demand available at CPFL (2012, p. 65), which illustrates the energy demand of the 24-h period observed from the Paulista Power and Light Company (CPFL), the supplier of low tension residential consumers in São Paulo state.

The demand rate can be calculated from the demand data, subsequently enabling the calculation of the consumption rate in sunlight periods through the areas under the curve. 
Equations (5) and (6) allow obtaining the sunrise and sunset times and sunlight periods, enabling to obtain the area under the demand curve in those periods through numerical integration. Here, the trapezoidal rule was used (ARENALES; DAREZZO, 2017, p. 213).

Thus the sunlight consumption rate $\left(\mathrm{K}_{m}^{k}\right)$ was obtained using the sunlight period area under the demand curve $\left(A S_{m}^{k}\right)$ and the total area under the demand curve $\left(A_{m}^{k}\right)$ :

$$
K_{m}^{k}=\frac{A S_{m}^{k}}{A_{m}^{k}} \text { with } i=1,2, \ldots, n \text { and } k=1,2 \ldots, 16
$$

The estimation of the yearly percentage of PV energy supply for municipality k was obtained as follows:

where

$$
E_{\text {year }}^{k}=\frac{100 \times F_{\text {year }}^{k}}{C_{\text {year }}^{k}}
$$

- $F_{\text {year }}^{k}$ is the estimation of the yearly PV generation for municipality k, given in kWh;

- $\mathrm{C}_{\text {year }}^{\mathrm{k}}$ is the average yearly consumption in sunlight periods for municipality $\mathrm{k}$, given in $\mathrm{kWh}$.

Parameter $\mathrm{F}_{\text {year }}^{\mathrm{k}}$ is given by

$$
\mathrm{F}_{\text {year }}^{\mathrm{k}}=\sum_{\mathrm{m}=1}^{12} \mathrm{~F}_{\mathrm{m}}^{\mathrm{k}}
$$

where $\mathrm{F}_{\mathrm{m}}^{\mathrm{k}}$ is the PV energy generation potential for municipality $\mathrm{k}$ in month $\mathrm{m}$ - see equation (14).

The average yearly consumption in sunlight periods $\left(C_{\text {year }}^{k}\right)$ for the location of interest is given by

$$
C_{\text {year }}^{k}=K_{\text {year }}^{k} \times Q_{\text {year }}^{k}
$$

where

- $\mathrm{K}_{\text {year }}^{\mathrm{k}}$ is the average consumption rate of sunlight periods for municipality $k$, assuming values between 0 and 1 ;

- $Q_{\text {year }}^{k}$ is the yearly consumption for municipality k according to São Paulo (2018, p. 23), given in kWh.

For municipality $k$, the $K_{\text {year }}^{k}$ parameter is the $K_{m}^{k}$ yearly mean - see equation (17):

$$
\mathrm{K}_{\text {year }}^{\mathrm{k}}=\frac{1}{12} \sum_{\mathrm{m}=1}^{12} \mathrm{~K}_{\mathrm{m}}^{\mathrm{k}}
$$


Therefore, from equations (17) and (22), the consumption in sunlight periods for each municipality was obtained, and, afterwards, the monthly and yearly PV energy supply was estimated using equations (16) and (20) respectively.

\subsection{ASSESSMENT OF SUSTAINABILITY AND ENVIRONMENTAL PERFORMANCE}

To expand the analysis described so far, it is also necessary to analyze the PV use considering aspects of sustainability and environmental performance, considering sustainability in the environmental, economic and social aspects (GOLDEMBERG, 2015, p. 34).

The energy payback time (EPBT) and the rate of greenhouse gas (GHG) emissions are environmental indicators that allow the assessment of the sustainability and environmental performance of these systems (PENG; LU; YANG, 2013, p. 256).

According to Frischknecht et al. (2016, p. 16), the EPBT can be defined as "the period required for a renewable energy system to generate the same amount of energy (in terms of primary energy equivalent) that was used to produce the system itself", while GHG is responsible for maintaining high-temperature levels in the atmosphere - global warming potential - expressed as the equivalent mass of $\mathrm{CO}_{2}$ (PENG; LU; YANG, 2013, p. 257). EPBT and GHG emissions also take into account the energy consumption and gas emissions of the whole life cycle of the system, from the process of manufacturing to transportation, installation and final use, decommissioning or recycling (PENG; LU; YANG, 2013, p. 256).

Peng, Lu and Yang (2013) offered a rich overview on EPBT and GHG emissions in the assessment of the life cycle of PV systems, where a great data analysis on those parameters is found. Lima, Toledo and Bourikas (2021), Wu et al. (2017) and Yue, You and Darling (2014) are among other studies that also offered data in that sense, where in Lima, Toledo and Bourikas (2021) considered PV power plants in Brazil.

Taking into account that most commercial PV modules were based on crystalline silicon cells, among which the monocrystalline silicon cells (mono-Si) have the highest efficiency, this section focuses on data and information on monocrystalline PV (TOLMASQUIM, 2016, p. 336).

The EPBT can be obtained as follows (LIMA; TOLEDO; BOURIKAS, 2021; YUE; YOU; DARLING, 2014):

$$
E P B T=\frac{E_{\text {input }}+E_{\text {BOS }}}{E_{\text {out put }} / n_{G}}
$$

where

- $E_{\text {in put }}$ is the primary energy input during the life cycle, in kWh;

- $E_{B \text { os }}$ is the energy requirement of the balance of system components (support structures, cabling, electronic and electrical components) in kWh;

- $\mathrm{E}_{\text {out put }}$ is the annual electricity generation of the PV system, in $\mathrm{kWh}$;

- $\mathrm{n}_{\mathrm{G}}$ is the average conversion rate of primary energy into the electricity grid in the country where the PV system is installed. 
The rate of GHG emissions is assessed in different studies that addressed sustainability features of the PV systems, such as in Lima, Toledo and Bourikas (2021), Lukac et al. (2016), Peng, Lu and Yang (2013), and Wild-Scholten (2013) being used as a parameter of sustainability assessment in an environmental sense. In the present study, the rate of GHG emissions was considered as $61 \mathrm{~g} \mathrm{CO} / \mathrm{kWh}$ for mono-Si PV systems (PENG; LU; YANG, 2013, p. 265). For comparison, the rate of GHG emissions from fossil fuels is estimated at $685 \mathrm{~g} \mathrm{CO2/kWh}$ (D'ADAMO, 2018, p. 10).

The expected lifetime for PV systems was also assessed in Peng, Lu and Yang (2013), and the mono-Si solar cells have indicated a 30-year lifetime. Additionally, as the present analysis takes into residential account systems, distributed grid-connected, and do not use energy storage, low-capacity inverters presented a 15-year lifetime (PENG; LU; YANG, 2013, p. 263).

On the other hand, regarding the PV energy production system and efficiency estimations for planning purposes, one must consider the most accurate technical information on the module's material must be considered (mono-Si solar cells, for instance) to increase accuracy estimation (NERO et al., 2020, p. 182). In that sense, planning goals are more realistic and achievable.

Regarding the economic aspect, it is essential to consider information on energy generation and energy demand. In an urban environment and considering distributed PV generation, it implies using the available roof area together with solar radiation data (NERO et al., 2020, p. 183; SANTOS et al., 2014, p. 49). Besides, distributed generation tends to decrease financial losses caused by the discontinuity of energy supply related to centralized generation. This type of information and data can lead to a solid background for decision making by the public administrator regarding sustainable urban planning (FONSECA; SCHLUETER, 2015, p. 263; NERO et al., 2020, p. 183).

Regarding the social aspect, the short term effects are also related to GHG emissions, their potential air pollution, and the risk factors associated with human health, as well as their global warming potential (ONAT; BAYAR, 2010, p. 3113).

Another social sustainability feature regards energy supply security and diversity. Here, the intermittency of electric supply represents an important issue in the security context (SANTOYO CASTELAZO; AZAPAGIC, 2014, p. 122), and PV distributed generation might increase this security. Furthermore, PV distributed generation increases the supply diversity in the Brazilian electric matrix, since it mostly consists of hydroelectric generation.

The physical, geographical, and technical PV potential data can also be linked to social sustainability, relating social parameters such as energy demand per capita, population density, population distribution, building characteristics (area, height, and property values), and PV systems already installed (NERO et al., 2020, p. 183).

\section{RESULTS AND DISCUSSION}

The estimations of PV generation and energy supply were obtained using specific information for each municipality studied. Information is shown in Table 2. Since all municipalities in the study are located left of the Greenwich meridian and in the same timezone, the values of $\mathrm{SL}$ were defined as equal to $45^{\circ}$ - see equation (4).

The municipalities studied presented different population classes, based on available data, to increase the scope of analysis. 


\subsection{SUN'S DAILY PATH}

The Sun's daily path was obtained according to the solar altitude angle (a) and the solar azimuth angle ( $\mathrm{z}$ ), as described in section 2.2. The a parameter changes with a solar declination $(\delta)$ and hour angle (h).

The hour angle ( $h$ ) changes according to the local standard time of the day (LST), which was obtained from sunrise $\left(h_{S R}\right)$ and sunset $\left(h_{S S}\right)$ times and day length $(D L)$.

Table 2 | Database used for the estimation of PV energy generation and supply.

\begin{tabular}{cccccc}
\hline City & $I d(\mathrm{k})$ & $\begin{array}{c}\text { Consumption* } \\
(\mathrm{kWh})\end{array}$ & $\begin{array}{c}\text { Urban area } \\
(\mathrm{km})\end{array}$ & Latitude $\left(^{\circ}\right)$ & Longitude $\left(^{\circ}\right)$ \\
\hline Águas de São Pedro & 1 & $15,058,321$ & 1.68 & -22.6001 & -47.8758 \\
\hline Águas de Lindoia & 2 & $46,827,867$ & 3.86 & -22.4767 & -46.6250 \\
\hline Ourinhos & 3 & $206,322,667$ & 32.21 & -22.9831 & -49.8788 \\
\hline Bauru & 4 & $921,831,447$ & 75.59 & -22.3154 & -49.0704 \\
\hline Piracicaba & 5 & $2,012,793,035$ & 94.53 & -22.7250 & -47.7012 \\
\hline Jundiaí & 6 & $2,000,088,619$ & 101.28 & -23.1865 & -46.8888 \\
\hline Santos & 7 & $1,391,860,105$ & 34.08 & -23.9618 & -46.3264 \\
\hline São José do Rio Preto & 8 & $1,157,750,507$ & 108.3 & -20.8202 & -49.3767 \\
\hline Sorocaba & 9 & $2,037,935,190$ & 122.31 & -23.5062 & -47.4582 \\
\hline Ribeirão Preto & 10 & $1,856,404,675$ & 134.9 & -21.1767 & -47.8097 \\
\hline Osasco & 11 & $1,446,265,175$ & 60.42 & -23.5317 & -46.7973 \\
\hline São José dos Campos & 12 & $1,918,025,049$ & 120.19 & -23.1791 & -45.8956 \\
\hline Santo André & 13 & $2,791,481,294$ & 63.4 & -23.6666 & -46.5254 \\
\hline São Bernardo do & 14 & $2,644,526,692$ & 83.58 & -23.6944 & -46.5616 \\
Campo & 15 & $3,242,013,676$ & 241.09 & -22.9064 & -47.0643 \\
\hline Campinas & 16 & $3,175,476,963$ & 144.65 & -23.4635 & -46.5241 \\
\hline Guarulhos & & & & & \\
\hline
\end{tabular}

*Consumption observed for 2017.

Source: São Paulo (2018, p. 23), IBGE (2020).

Figure 3 shows the average Sun's daily path for each average day length in a month in the municipality of Sorocaba. They have been obtained from the Sun's daily path vector $(\vec{s})$ for each minute of each average day length in a month.

The grey plane is normal to the horizontal plane in the East-West line, and the arrow indicates the true North direction. It is possible to see in January, February, November, and December that the Sun remained most of the day on the southern side of the grey plane, resulting in higher sunlight incidence for south-oriented PV modules in those months.

However, the highest yearly average sunlight incidence occurs for north-oriented modules, as the Sun is most of the time at the northern side of the East-West line. Such details are discussed in section 3.3. 


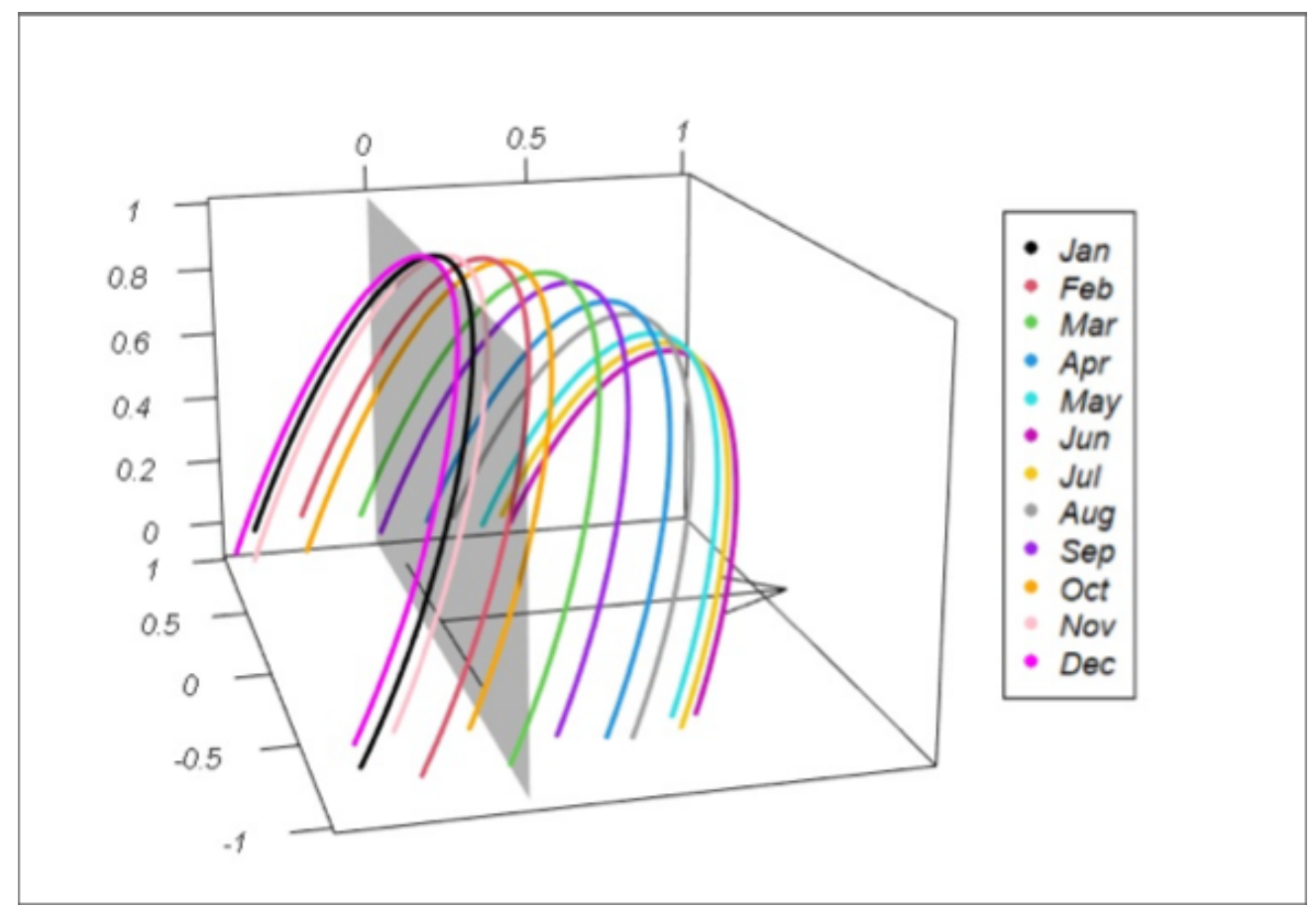

Figure 3 | Sun's daily path in each average day length in a month, for the municipality of Sorocaba.

Source: Own elaboration.

\subsection{AVAILABLE AREA}

The available area for PV modules was considered the same as the roof areas estimated in the municipalities. Section 2.3 describes the methodology used.

Data of the urbanized area ( $A_{u r b}^{k}$ ) data were obtained from IBGE (2020) and are shown in Table 3, as well as the total area, the estimated roof proportion $\left(A T^{k}\right)$ and the estimated roof area $\left(-T_{k}\right)$.

\subsection{PHOTOVOLTAIC ENERGY GENERATION AND SUPPLY POTENTIAL}

The estimation of PV energy generation for each municipality per month was obtained using equation (14) in section 2.4, according to the average monthly solar radiation $\left(\mathrm{I}_{\mathrm{m}}^{\mathrm{k}}\right)$, given in $\mathrm{kWh} / \mathrm{m}^{2}$, and the factor average direct solar incidence on the PV module $\left(\mathrm{H}_{\mathrm{m}}^{\mathrm{k}}\right)$. Table 4 shows the obtained values for $\mathrm{I}_{\mathrm{m}}^{\mathrm{k}}$,

$\mathrm{H}_{\mathrm{m}}^{\mathrm{k}}$ for each municipality $\mathrm{k}$ in the month $\mathrm{m}$ was obtained from the mean monthly projections of the Sun path vector $(\vec{s})$ and the normal to the PV module surface vector $(\vec{h})$, minute by minute, for each average day length in a month and changing azimuth surface angle $Z_{S}$, as described in sections 2.1 and 2.2.

Figure 4 shows the variation of $\mathrm{s}$ on $\mathrm{n}$ projection mean (vertical axis), in the municipality of Sorocaba (9), according to $Z_{s}$ angle (horizontal axis), for each average day length in a month. Each point represents the mean projection of $s$ on $n$ along each average day length, for every fixed $Z_{s}$ value in $\{0,15, \ldots, 360\}$. 
Table 3 | Total area, urban area, roof average proportion, and roof estimated area for the municipalities studied.

\begin{tabular}{|l|c|c|c|c|c|}
\hline \multicolumn{1}{|c|}{ City } & Id $(\mathrm{k})$ & Area $\left(\mathrm{km}^{2}\right)$ & Urban area $\left(\mathrm{km}^{2}\right)$ & $\begin{array}{c}\text { Roof } \\
\text { proportion }(\%)\end{array}$ & $\begin{array}{c}\text { Roof } \\
\text { area }\left(\mathrm{km}^{2}\right)\end{array}$ \\
\hline Águas de São Pedro & 1 & 3.61 & 1.68 & 16.12 & 0.27 \\
Águas de Lindoia & 2 & 60.13 & 3.86 & 16.14 & 0.62 \\
Ourinhos & 3 & 295.82 & 32.21 & 28.50 & 9.18 \\
Bauru & 4 & 667.68 & 5.59 & 31.47 & 23.79 \\
Piracicaba & 5 & 1378.07 & 4.53 & 25.56 & 24.16 \\
Jundiaĺ & 6 & 431.21 & 101.28 & 18.44 & 18.67 \\
Santos & 7 & 281.03 & 34.08 & 27.87 & 9.50 \\
São José do Rio Preto & 8 & 431.94 & 108.30 & 31.39 & 34.00 \\
Sorocaba & 9 & 450.38 & 122.31 & 27.71 & 33.90 \\
Ribeirão Preto & 10 & 650.92 & 134.90 & 27.90 & 37.64 \\
Osasco & 11 & 64.95 & 60.42 & 33.25 & 20.09 \\
São José dos Campos & 12 & 1099.41 & 120.19 & 37.27 & 44.80 \\
Santo André & 13 & 175.78 & 63.40 & 34.73 & 22.02 \\
São Bernardo do Campo & 14 & 409.53 & 83.58 & 26.33 & 22.01 \\
Campinas & 15 & 794.57 & 241.09 & 24.96 & 60.17 \\
Guarulhos & 16 & 318.68 & 144.65 & 26.09 & 37.74 \\
\hline
\end{tabular}

Source: Data from IBGE $(2019,2020)$.

Values of $\mathrm{H}_{\mathrm{m}}^{9}$ by month have been obtained using the mean vertical axis values of each graph and are shown in Figure 5. Values of $\mathrm{H}_{\mathrm{m}}^{\mathrm{k}}$ were obtained similarly from the respective values shown in each graph of Figure 5.

In Figure 4, the relationship between the Sun path, described in Figure 3, and the behaviour of the mean is observed. For January, February and December, the highest values for the projection of $\vec{s}$ on $\vec{h}$ occur when $Z_{S}$ is close to $180^{\circ}$ as the Sun remains most of the time at the southern side of the EastWest plane in those months - see Figure 9. It has been defined that $Z_{s}=0^{\circ}$ means that the PV module surface is North oriented, being westwards for the positive direction.

Table 4 | Monthly average solar radiation $\left(\mathrm{I}_{\mathrm{m}}^{\mathrm{k}}\right)$ obtained values, given in $\mathrm{kWh} / \mathrm{m}^{2}$.

\begin{tabular}{|c|c|c|c|c|c|c|c|c|c|c|c|c|}
\hline Id(k) & jan & feb & mar & apr & may & jun & jul & aug & sep & oct & nov & dec \\
\hline 1 & 150.97 & 150.08 & 159.34 & 157.50 & 143.22 & 136.50 & 143.53 & 172.67 & 152.70 & 161.82 & 153.00 & 164.30 \\
\hline 2 & 155.93 & 153.16 & 162.75 & 159.60 & 150.04 & 141.00 & 151.28 & 172.05 & 157.80 & 166.47 & 156.30 & 164.92 \\
\hline 3 & 159.03 & 154.84 & 166.16 & 159.30 & 142.29 & 133.50 & 143.22 & 170.50 & 150.90 & 163.37 & 162.30 & 174.53 \\
\hline 4 & 159.34 & 156.52 & 166.47 & 160.20 & 147.25 & 137.40 & 148.49 & 171.74 & 153.60 & 168.95 & 162.90 & 173.60 \\
\hline 5 & 156.55 & 154.00 & 162.75 & 157.50 & 145.39 & 138.00 & 145.70 & 170.50 & 153.90 & 163.99 & 157.20 & 167.40 \\
\hline 6 & 154.07 & 152.32 & 160.89 & 154.50 & 142.29 & 135.00 & 141.98 & 168.95 & 151.50 & 162.75 & 155.70 & 168.02 \\
\hline 7 & 138.26 & 136.92 & 135.47 & 129.30 & 120.28 & 108.00 & 110.98 & 126.17 & 107.10 & 113.15 & 120.60 & 137.33 \\
\hline 8 & 161.82 & 156.24 & 164.30 & 162.00 & 154.38 & 148.80 & 160.58 & 183.83 & 162.00 & 169.88 & 162.60 & 169.88 \\
\hline 9 & 155.62 & 153.44 & 158.72 & 151.20 & 138.88 & 131.40 & 136.71 & 163.99 & 148.20 & 158.10 & 154.50 & 168.64 \\
\hline 10 & 159.03 & 158.48 & 163.99 & 161.70 & 155.00 & 150.30 & 160.58 & 179.18 & 159.00 & 167.09 & 158.40 & 168.64 \\
\hline 11 & 146.94 & 147.28 & 150.66 & 143.40 & 132.99 & 124.80 & 129.89 & 157.17 & 135.90 & 144.15 & 142.80 & 158.41 \\
\hline 12 & 151.59 & 151.20 & 153.76 & 144.90 & 130.51 & 124.50 & 130.82 & 157.79 & 139.80 & 151.28 & 144.30 & 160.27 \\
\hline 13 & 141.36 & 143.92 & 144.77 & 136.80 & 126.48 & 117.90 & 123.69 & 145.70 & 127.50 & 134.54 & 135.90 & 151.90 \\
\hline 14 & 143.22 & 144.20 & 146.63 & 138.60 & 128.03 & 120.00 & 125.24 & 148.49 & 129.90 & 136.40 & 138.00 & 153.45 \\
\hline 15 & 157.17 & 153.72 & 162.13 & 157.50 & 146.01 & 138.60 & 146.94 & 170.19 & 154.80 & 166.16 & 156.00 & 168.33 \\
\hline 16 & 147.25 & 147.56 & 150.35 & 142.80 & 129.89 & 124.80 & 129.58 & 155.93 & 135.00 & 143.22 & 139.50 & 155.93 \\
\hline \hline
\end{tabular}

Source: Data from Crecesb (2020).

The $\mathrm{H}_{\mathrm{m}}^{\mathrm{k}}$ behaviours for all municipalities are illustrated in Figure 6, where the vertical axis indicates $\mathrm{H}_{\mathrm{m}}^{\mathrm{k}}$ values and are limited between 0.4 and 0.65 . The horizontal axis indicates the months. Few changes in the behaviour of this parameter were observed from one municipality to the other. 
Each point in the graphs in Figure 5 indicate the mean projection of $\vec{s}$ on $\vec{h}$, for all $Z_{s}$ values in each average day length in a month. For instance, in the case of Sorocaba, each point in its graph in Figure 5 is the mean of the observed values of the graph of the respective month in Figure 4.

In Figure 6, the highest potential was observed for the municipality of Campinas, followed by São José dos Campos. These municipalities presented the highest estimations of roof area, as shown in Table 5, which shows the municipalities ordered decreasingly by values of estimated roof area.
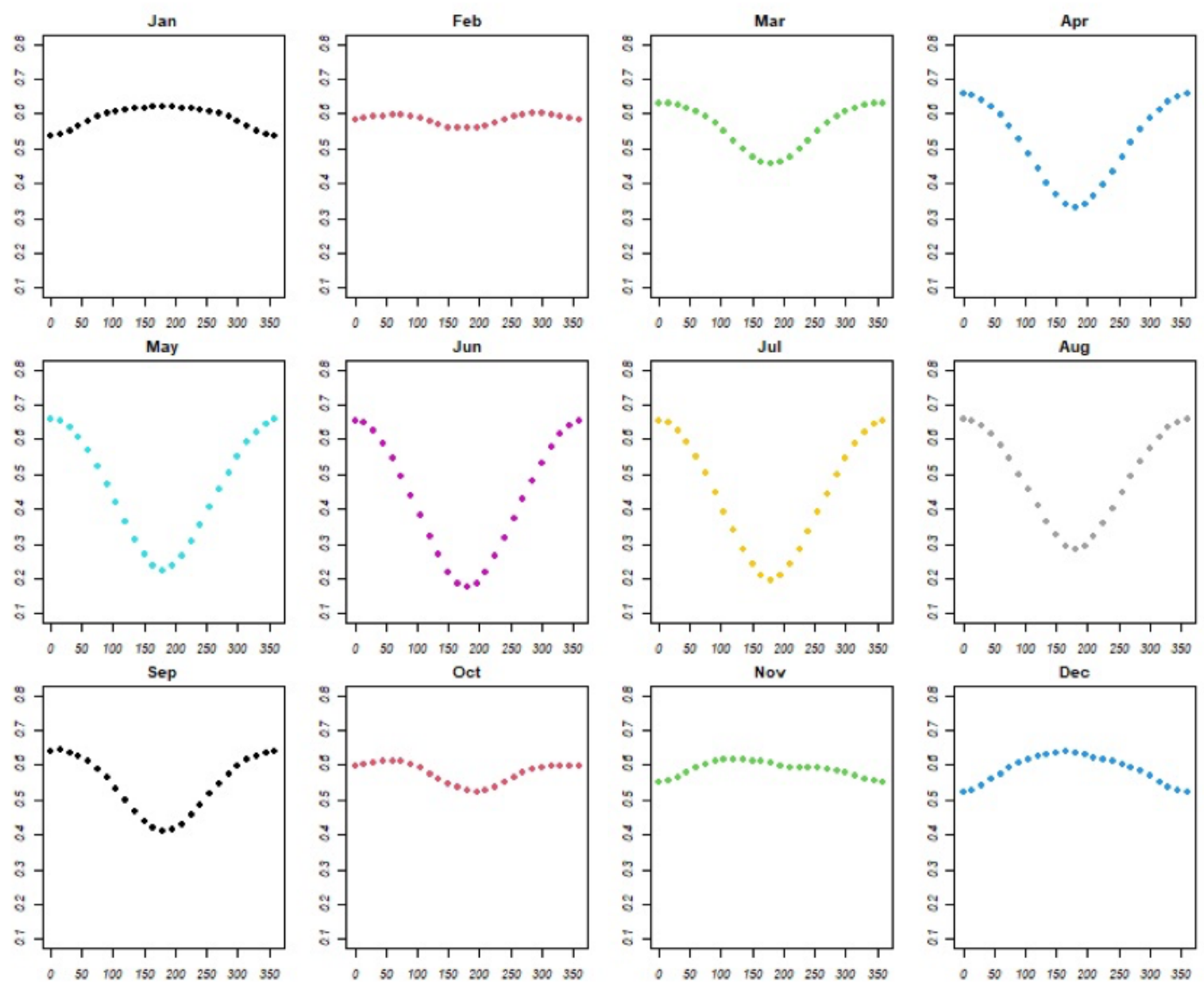

Figure 4 | Projection for the monthly means of $\rightarrow$ S on $\rightarrow$ n (vertical axis), according to $Z_{s}$ (horizontal axis) for the municipality of Sorocaba.

Source: Own elaboration. 

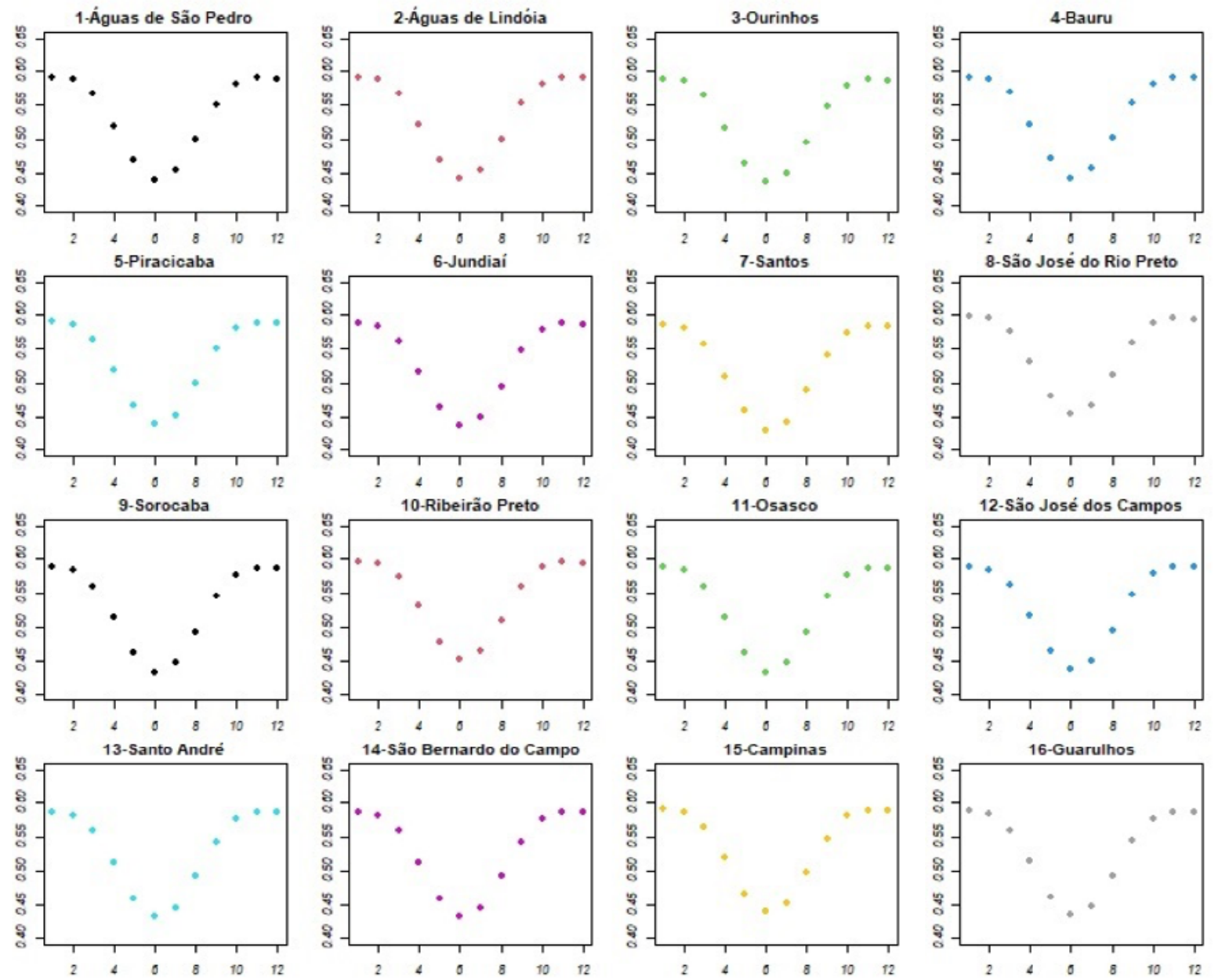

Figure $5 \mid \mathrm{H}_{\mathrm{m}}^{\mathrm{k}}$ values (vertical axis) by month (horizontal axis), for each municipality.

\section{Source: Own elaboration.}

It was also noticed that higher roof areas did not necessarily mean higher generation potential in situations where two municipalities have similar roof areas, such as in Guarulhos and Ribeirão Preto. In this case, Ribeirão Preto has a higher generation potential. Mean monthly solar radiation $\left(\mathrm{I}_{\mathrm{m}}^{\mathrm{k}}\right)$ and the factor average direct solar incidence in the panels $\left(H_{m}^{k}\right)$ have a more significant influence on the PV energy generation potential.

Thus, it is possible to verify that, for the municipalities studied, the generation potential is directly related to the roof area. Looking at $\mathrm{I}_{\mathrm{m}}^{\mathrm{k}}$ and $\mathrm{H}_{\mathrm{m}}^{\mathrm{k}}$ parameters, which range according to the city location, it can be seen that the small variations observed from one municipality to the other do not significantly affect the PV generation potential.

In addition, for municipalities with similar roof areas, $\mathrm{I}_{\mathrm{m}}^{\mathrm{k}}$ and $\mathrm{H}_{\mathrm{m}}^{\mathrm{k}}$ have greater influence in the PV energy generation potential, as observed in the numbers obtained for São José do Rio Preto and Sorocaba. 

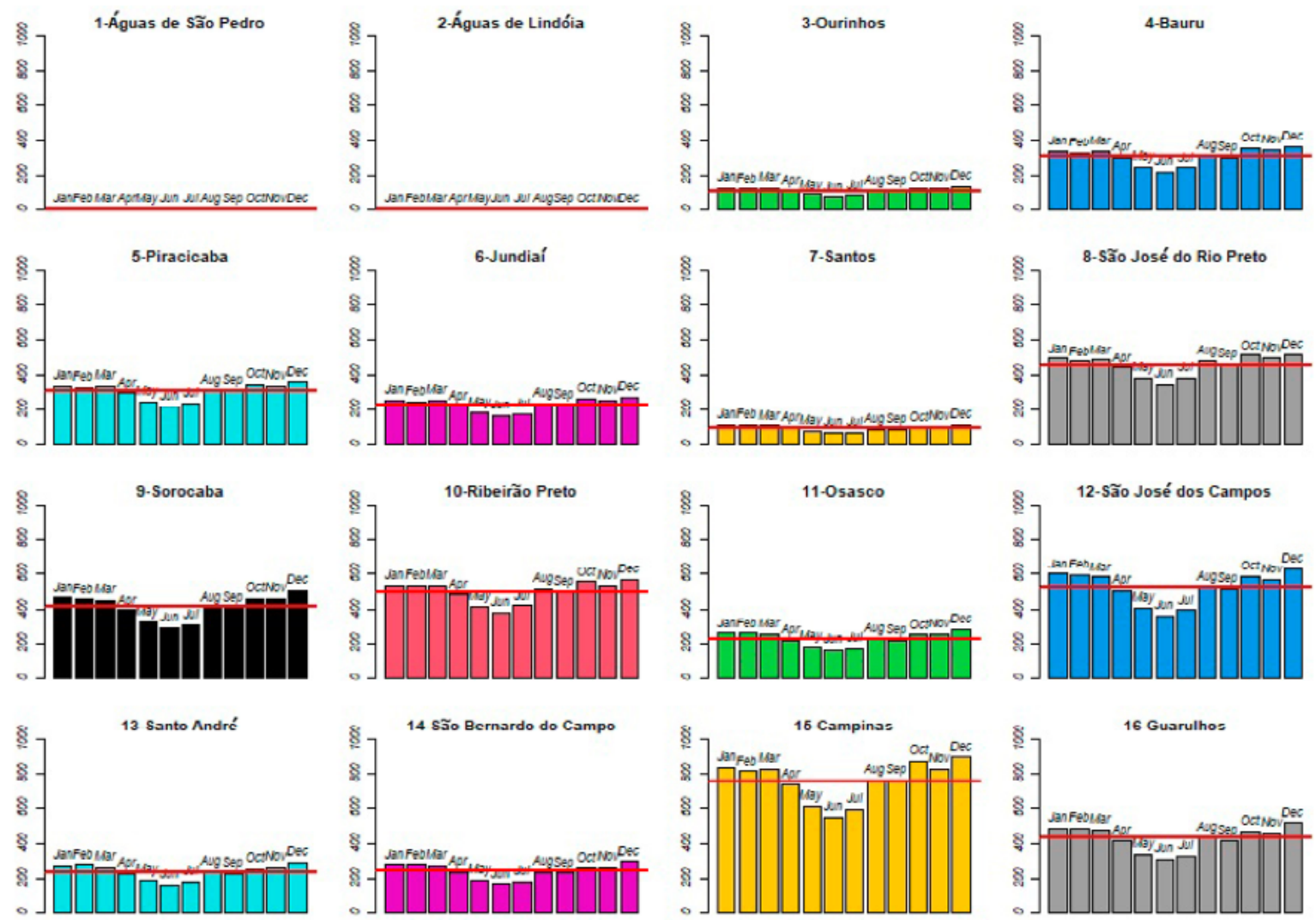

Figure 6 | Monthly PV energy generation potential, given in GWh.

\section{Source: Own elaboration.}

After estimating the PV energy generation, monthly and annual energy supply potentials were calculated using equations (16) and (20).

Since the methods for energy storage were not considered, the supply potentials were obtained according to the consumption in the sunlight periods, using equations (17) and (22).

Monthly PV energy supply depends on the average monthly consumption in sunlight periods $\left(C_{m}^{k}\right)$, according to equation (16).

The monthly PV energy supply ( $E_{m}^{k}$ ) was obtained using the PV energy generation potential ( $F_{m}^{k}$ ) and the average consumption in sunlight periods $\left(C_{m}^{k}\right)$ for each municipality, using equation (16). The results are shown in Figure 7. 

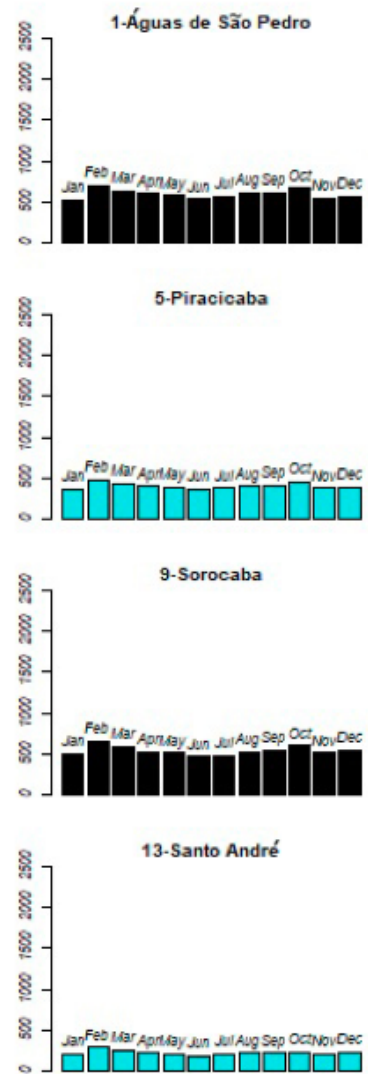
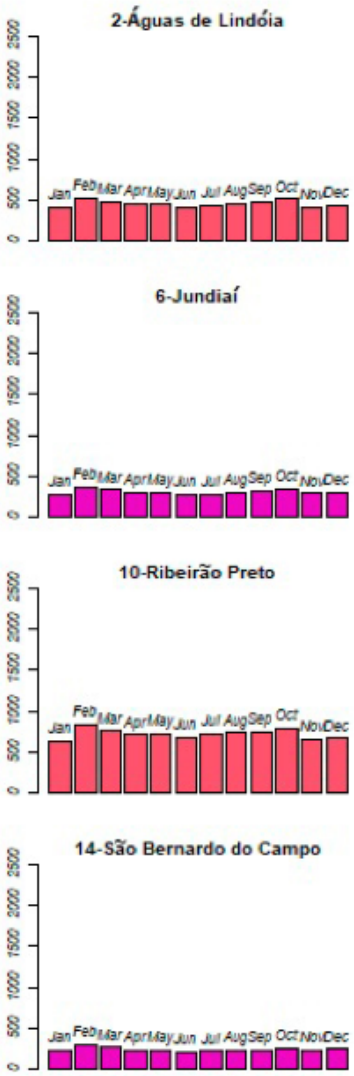
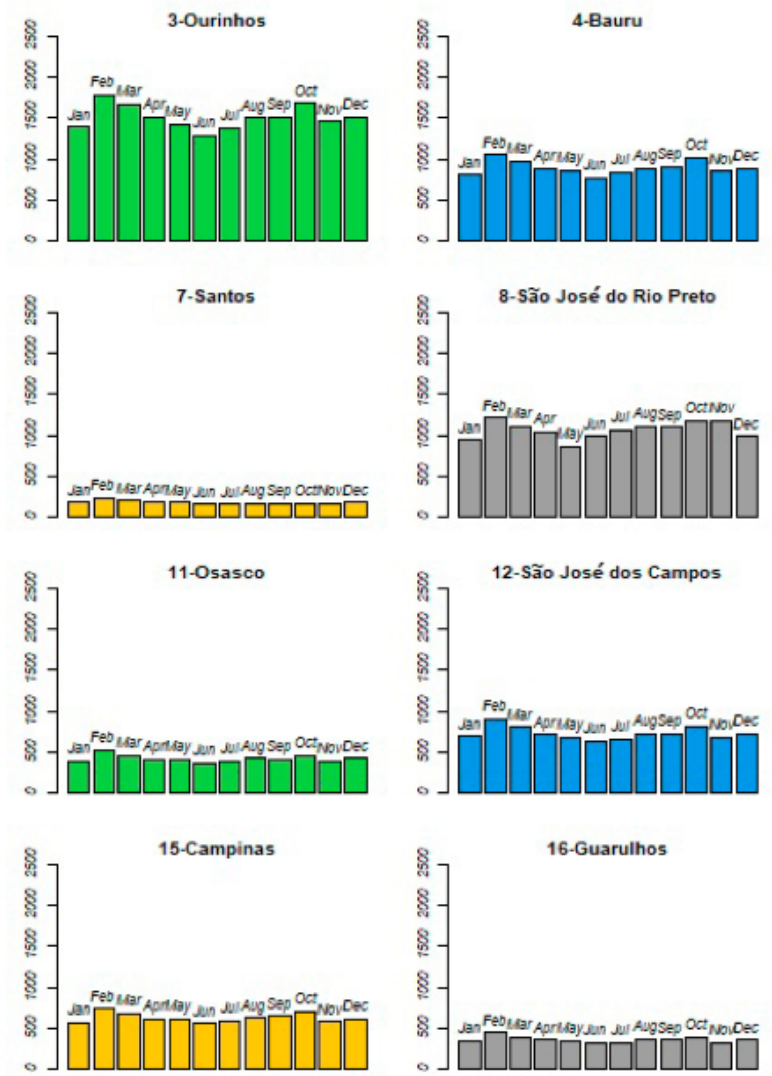

Figure 7 | Potential monthly PV energy supply, in percentage (\%).

\author{
Source: Own elaboration.
}

The results show that all the municipalities studied, $\mathrm{E}_{\mathrm{m}}^{\mathrm{k}}$ was greater than $100 \%$. It means that the consumption in sunlight periods could have been supplied by PV energy for the municipalities studied, as long as the entire roof area was covered with PV modules.

As aforementioned, $E_{m}^{k}$ depends on the PV energy generation potential $\left(F_{m}^{k}\right)$ and the average consumption in sunlight periods $\left(C_{m}^{k}\right)$. Thus, municipalities with low generation potential may have high supply potential due to low consumption in sunlight periods, as occurs in Ourinhos. Likewise, municipalities with high generation potential, such as Campinas, may have lower supply potential due to higher consumption in sunlight periods.

Some analyzes were carried out to clarify the possible influence of some variables over energy consumption. The first analysis addressed the relationship between energy consumption and the population of a given municipality.

A scatter plot with energy consumption and the population is shown in Figure 8(a) and highlights a trend of linear growth in energy consumption linear with population. The linear fit line is also shown in the figure. The 0.912 linear correlation factor was obtained between energy consumption and population, showing a substantially positive linear behaviour.

The relationship between energy consumption and roof area also was analyzed, since both affect the PV energy supply. Figure 8 (b) illustrates the respective scatter plot.

The linear correlation factor between energy consumption and roof area $(0.731)$ indicates a positive linear relationship, although not so strong as the previous one, indicating that an increase in energy consumption might not represent an increase in the roof area in the same proportion. 
Table 5 shows the roof area, energy consumption, and population data, decreasingly ordered according to the roof area. From this data, it is possible to observe that the parameters of consumption and population do not change in the same way as the roof area parameters. This context allows understanding the $1,500 \%$ PV supply of Ourinhos even with relatively low generation potential, as well as the numbers obtained for the municipality of Campinas, which shows high generation potential but an average supply potential due to high energy consumption.

As mentioned in section 2.4, the yearly supply potential was also obtained using equation (20). This parameter depends on the yearly PV energy generation potential $\left(F_{\text {year }}^{k}\right)$ and on the yearly mean consumption in sunlight periods ( $C_{\text {year }}^{k}$ ) - see equations (21) and (22). The values obtained for these parameters are shown in Table 6, decreasingly ordered according to the generation potential.

It is also possible to notice from Table 6 that the generation potential does not behave like energy consumption due to the aspects previously discussed, highlighting that high energy generation potential does not necessarily mean high energy supply potential.

The yearly energy supply potential was estimated from data in Table 6, shown in Figure 9.

\subsection{ASSESSMENT OF SUSTAINABILITY AND ENVIRONMENTAL PERFORMANCE}

As mentioned in section 2.5, the EPBT and the rate of GHG emissions, together with the life cycle analysis, are parameters that allow assessing the sustainability and environmental performance of PV systems.

(a)

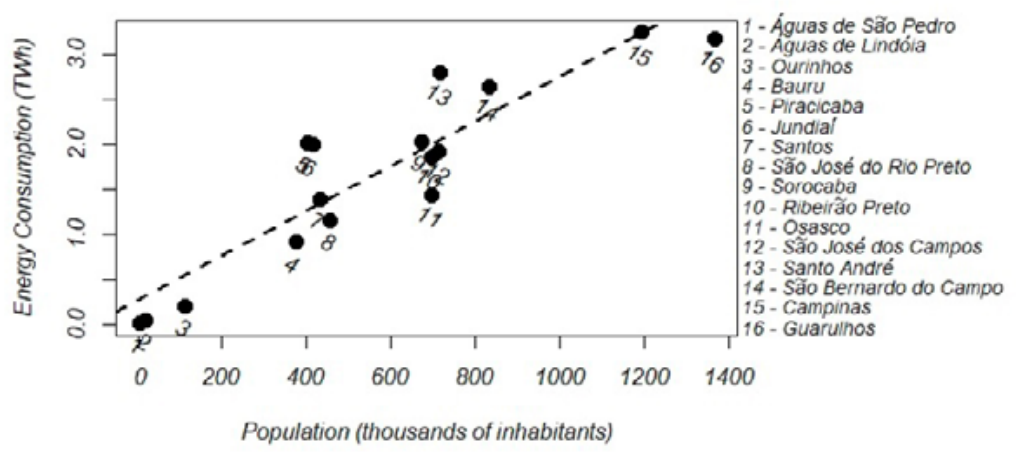

(b)

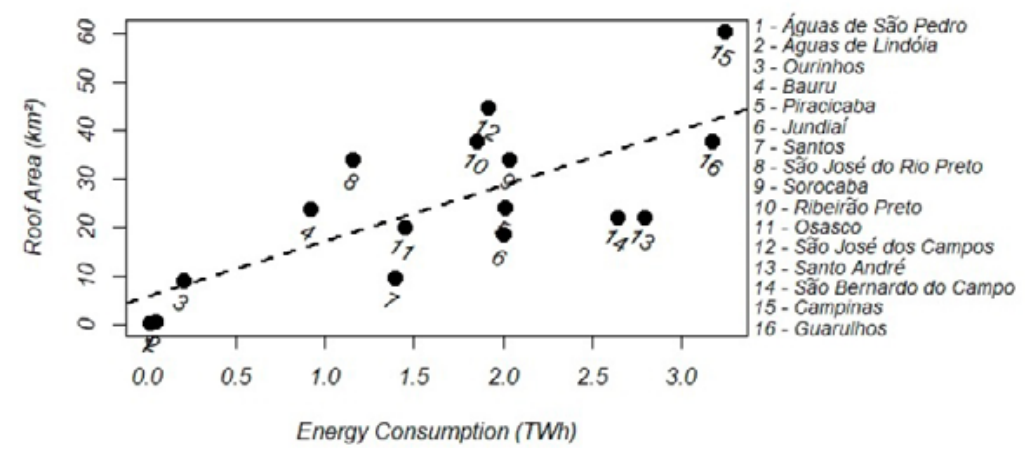

Figure 8 | Scatter plots with energy consumption and population (a) and energy consumption and roof area

(b), with linear fit lines.

Source: Own elaboration. 
According to data available in Peng, Lu and Yang (2013) and Wu et al. (2017), mono-Si PV modules $E_{B O S}$ were defined for each municipality studied with the energy demand of BOS components multiplied by each respective estimation of roof area given in Table 3. Then, with equation (24), the EPBT for each city has been estimated.

\begin{tabular}{|l|c|c|c|c|}
\hline \multicolumn{1}{|c|}{ City } & Id (k) & $\begin{array}{c}\text { Roof area } \\
\left(\mathrm{km}^{2}\right)\end{array}$ & $\begin{array}{c}\text { Energy } \\
\text { consumption }(\mathrm{kWh})\end{array}$ & Population \\
\hline Campinas & 15 & 60.165 & $3,242,013,676$ & $1,194,094$ \\
\hline São José dos Campos & 12 & 44.798 & $1,918,025,049$ & 713,943 \\
\hline Guarulhos & 16 & 37.739 & $3,175,476,963$ & $1,365,899$ \\
\hline Ribeirão Preto & 10 & 37.642 & $1,856,404,675$ & 694,534 \\
\hline São José do Rio Preto & 8 & 33.997 & $1,157,750,507$ & 456,245 \\
\hline Sorocaba & 9 & 33.896 & $2,037,935,190$ & 671,186 \\
\hline Piracicaba & 5 & 24.159 & $2,012,793,035$ & 400,949 \\
\hline Bauru & 4 & 23.789 & $921,831,447$ & 374,272 \\
\hline Santo André & 13 & 22.016 & $2,791,481,294$ & 716,109 \\
\hline São Bernardo do Campo & 14 & 22.008 & $2,644,526,692$ & 833,240 \\
\hline Osasco & 11 & 20.092 & $1,446,265,175$ & 696,850 \\
\hline Jundiaí & 6 & 18.672 & $2,000,088,619$ & 414,810 \\
\hline Santos & 7 & 9.498 & $1,391,860,105$ & 432,957 \\
\hline Ourinhos & 3 & 9.18 & $206,322,667$ & 112,711 \\
\hline Águas de Lindóia & 2 & 0.623 & $46,827,867$ & 18,599 \\
\hline Águas de São Pedro & 1 & 0.271 & $15,058,321$ & 3,380 \\
\hline
\end{tabular}

Table 5 | Roof area, energy consumption, and population ordered decreasingly ordered according to roof area.

$$
\text { Source: Data from IBGE (2020), São Paulo (2018, p. 23) and IBGE (2019). }
$$

The total energy demand of BOS components obtained was $19.44 \mathrm{kWh} / \mathrm{m}^{2}$ for support and cabling (PENG; LU; YANG, 2013, p. 263) and $25.87 \mathrm{kWh} / \mathrm{m}^{2}$ for the inverter (WU et al., 2017, p. 72), while $\mathrm{n}_{\mathrm{G}}$ was considered to be 0.625 (LIMA; TOLEDO; BOURIKAS, 2021, p. 9).

$E_{\text {input }}$ was considered as $794.44 \mathrm{kWh} / \mathrm{m}^{2}$ by Peng, Lu and Yang (2013), also multiplied by each respective estimation of roof area. $\mathrm{E}_{\text {output }}$ was the yearly PV energy generation estimated for each municipality - see Table 6. The EPBT estimated for the municipalities studied are shown in Table 7.

The rate of GHG emissions was obtained for each municipality considering $61 \mathrm{~g} \mathrm{CO}_{2} / \mathrm{kWh}$ (PENG; LU; YANG, 2013, p. 265), and are shown in Table 7. The values represent the CO2 amount that would have been emitted during all life cycles of the PV systems considered.

The value for each municipality in Table 7 represents approximately $9.5 \%$ of all the GHG emissions that would have occurred in one year if the same amount of PV energy had been generated using fossil fuels, considering the emission rate of $685 \mathrm{~g} \mathrm{CO}_{2} / \mathrm{kWh}$. 
Table 6 | Yearly PV generation potential and consumption in sunlight periods, decreasingly ordered according to generation potential.

\begin{tabular}{|l|c|c|c|}
\hline \multicolumn{1}{|c|}{ City } & Id (k) & $\begin{array}{c}\text { Generation } \\
\text { potential (kWh) }\end{array}$ & $\begin{array}{c}\text { Sunlight periods } \\
\text { consumption } \\
(\mathrm{kWh})\end{array}$ \\
\hline Campinas & 15 & $9,098,009,791$ & $1,446,649,860$ \\
São José dos Campos & 12 & $6,276,436,007$ & $855,860,260$ \\
Ribeirão Preto & 10 & $5,978,571,442$ & $828,364,045$ \\
São José do Rio Preto & 8 & $5,458,623,695$ & $515,433,914$ \\
Guarulhos & 16 & $5,145,630,348$ & $1,416,959,878$ \\
Sorocaba & 9 & $4,941,689,180$ & $909,366,508$ \\
Bauru & 4 & $3,676,466,762$ & $411,339,207$ \\
Piracicaba & 5 & $3,650,558,284$ & $898,147,587$ \\
São Bernardo do Campo & 14 & $2,906,391,824$ & $1,180,039,491$ \\
Santo André & 13 & $2,870,918,144$ & $1,245,613,506$ \\
Jundiaí & 6 & $2,771,744,658$ & $892,478,629$ \\
Osasco & 11 & $2,757,781,453$ & $645,351,785$ \\
Ourinhos & 3 & $1,389,140,726$ & $92,065,206$ \\
Santos & 7 & $1,123,188,583$ & $621,075,179$ \\
Águas de Lindóia & 2 & $95,231,800$ & $20,895,509$ \\
Águas de São Pedro & 1 & $40,339,574$ & $6,719,317$ \\
\hline
\end{tabular}

Source: Data from São Paulo (2018, p. 23).

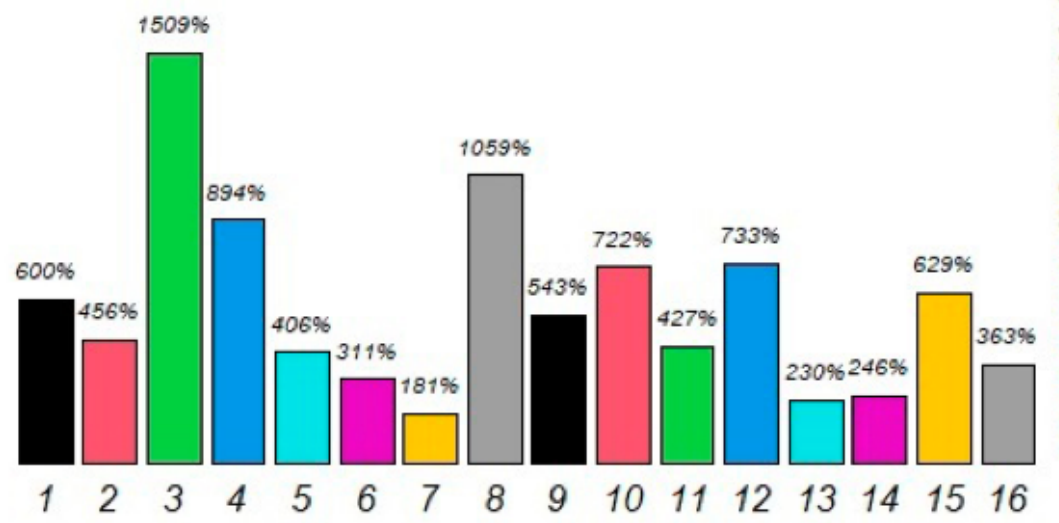

1 - Águas de São Pedro

2 - Aguas de Lindóia

3 - Ourinhos

4 - Bauru

5 - Piracicaba

6 - Jundiaí

7 - Santos

8 - São José do Rio Preto

9 - Sorocaba

10 - Ribeirão Preto

11 - Osasco

12 - São José dos Campos

13 - Santo André

14 - São Bernardo do Campo

15 - Campinas

16 - Guarulhos

Figure 9 | Yearly energy supply potential, in percentage (\%).

Source: Own elaboration.

It is also worth mentioning that, according to Peng, Lu and Yang (2013), the highest EPBT observed for mono-Si PV systems was 2.7 years, while its expected lifetime period was of 30 years. In Lima, Toledo and Bourikas (2021, p. 12), who considered Brazilian PV power plants, the highest EPBT observed was 4.69 years. 
Table 7 | EPBT estimated for the municipalities studied, in years, and GHG emissions estimated for the municipalities studied, in tons of $\mathrm{CO}_{2}$.

\begin{tabular}{ccc}
\hline City & EPBT (years) & GHG $\left(\right.$ tons of CO $\left._{2}\right)$ \\
\hline Águas de São Pedro & 3.1 & $2,622.07$ \\
\hline Águas de Lindóia & 3.0 & $6,190.01$ \\
\hline Ourinhos & 3.1 & $90,294.15$ \\
\hline Bauru & 3.0 & $238,970.34$ \\
\hline Piracicaba & 3.1 & $237,286.29$ \\
\hline Jundiaí & 3.1 & $180,163.40$ \\
\hline Santos & 3.9 & $73,007.26$ \\
\hline São José do Rio Preto & 2.9 & $354,810.54$ \\
\hline Sorocaba & 3.2 & $321,209.80$ \\
\hline Ribeirão Preto & 2.9 & $388,607.14$ \\
\hline Osasco & 3.4 & $179,255.79$ \\
\hline São José dos Campos & 3.3 & $407,968.34$ \\
\hline Santo André & 3.6 & $186,609.68$ \\
\hline São Bernardo do Campo & 3.5 & $188,915.47$ \\
\hline Campinas & 3.1 & $591,370.63$ \\
\hline Guarulhos & 3.4 & $334,465.97$ \\
\hline
\end{tabular}

Source: Own elaboration.

\section{CONCLUSIONS}

According to this study, the municipalities with the highest PV energy supply potential were Ourinhos, São José do Rio Preto, and Bauru, which have shown favourable rates of consumption and generation potential. As discussed in the previous section, these results depend mainly on the energy consumption and roof area of the municipalities. On the other hand, the municipalities with the highest PV generation potential are Campinas, Guarulhos, São Bernardo do Campo, and Santo André. However, due to high rates of consumption in the sunlight period, they presented lower energy supply potential. It must be emphasized that the energy supply potential was higher than $100 \%$ for every municipality studied, indicating that all the energy consumption could have been supplied by PV generation. São José do Rio Preto showed the lowest yearly energy supply potential, $180.85 \%$.

The results show that all the municipalities studied have the potential to reduce their dependence on centralized generation, at least during sunlight periods. To include the night periods in the analysis, some complementary forms of electric generation or energy storage may have to be considered.

Finally, the highest EPBT obtained was 8.6 years (Santos), which is far lower than the expected lifetime of 30 years of PV systems. This indicates that those systems would return the energy consumed during their life cycle in a relatively short period if compared with their expected lifetime. Besides, the estimates indicate that the PV systems would have generated approximately $9.5 \%$ of the GHG emissions if fossil fuels had been used to generate the same amount of energy. Regarding social and economic sustainability, distributed PV generation represents supply security and the improvement of diversification, decreasing the dependence of municipalities on centralized generation, allowing broader access to energy, and reducing discontinuity and maintenance costs. 
These results also bring a reflection to promote scientific arguments and subsidies capable of enhancing PV generation in Brazil, both from the point of view of natural potential and technical feasibility, since they have been obtained considering distributed generation from existing household structures. In addition, there are some possible directions for future works, like the analysis of the economic viability of installation costs and payback time.

\section{NOTES}

1. According to Aneel, Tonne of Oil Equivalent (toe) is a unit of energy, which one unity represents the amount of energy released by burning one tonne of crude oil.

2. The conversion efficiency was defined as equal to $15 \%$ as most commercial PV modules nowadays use silicon (Mono-Si) as their main component, and that is their lowest estimated efficiency (TOLMASQUIM, 2016, p. 340).

\section{REFERENCES}

ARENALES, S.; DAREZZO, A. Cálculo Numérico: aprendizagem com apoio de software. 2. ed. São Paulo: Cengage Learning, 2017. ISBN 978-85-221-1287-6.

ASSOULINE, D.; MOHAJERI, N.; SCARTEZZINI, J. Quantifying rooftop photovoltaic solar energy potential: a machine learning approach. Solar Energy, v. 141, p. 278-296, 2017.

BANCO DE INFORMAÇÕES DE GERAÇÃO. Agência Nacional de Energia Elétrica - Aneel. Available at: http://www2. aneel.gov.br. Accessed on: set. 2019.

BRASIL. Balanço energético nacional 2019: ano-base 2018. Rio de Janeiro: Empresa de Pesquisa Energética EPE, 2019.

CPFL. Caracterização da Carga da CPFL Paulista. Available at: http://www.consultaesic.cgu.gov.br/busca/dados/ Lists/Pedido/Attachments/564587/RESPOSTA_PEDIDO_Relatrio\%20de\%20Caracterizao\%20da\%20Carga\%20 -\%20PAULISTA.pdf. Accessed on: maio, 2020.

CRECESB. Centro de Referência para as Energias Solar e Eólica Sérgio de S. Brito. Ministério de Minas e Energia MME. Available at: http://www.cresesb.cepel.br/index.php?section=sundata. Accessed on: jan. 2020.

D'ADAMO, I. The profitability of residential photovoltaic systems. A new scheme of subsidies based on the price of $\mathrm{CO} 2$ in a developed PV market. Social Sciences, v. 7, n. 148, p. 21, 2018.

FONSECA, J. A.; SCHLUETER, A. Integrated model for characterization of spatiotemporal building energy consumption patterns in neighborhoods and city districts. Applied Energy, v. 142, p. 247-265, 2015.

FRISCHKNECHT, R. et al. Methodology guidelines on life cycle assessment of photovoltaic electricity. 3. ed. [S.I.], 2016. Report.

GOLDEMBERG, J. Energia e sustentabilidade: revista de cultura e extensão, 2015.

INSTITUTO BRASILEIRO DE GEOGRAFIA E ESTATÍSTICA. Available at: https://cidades.ibge.gov.br/. Accessed on: set. 2019. 
INSTITUTO BRASILEIRO DE GEOGRAFIA E ESTATÍSTICA. DGC/Coordenação de Geografia, DGC/Coordenação de Cartografia. Available at: https://www.ibge.gov.br/geociencias/cartas-e-mapas/redes-geograficas/15789-areasurbanizadas.html?=\&t=downloads. Accessed on: jul. 2020.

INSTITUTO NACIONAL DE METEOROLOGIA. Estações meteorológicas de observação de superfície automática. Instituto Nacional de Meteorologia. Ministério da Agricultura, Pecuária e Abastecimento. Available at: http:// www.inmet.gov.br/. Accessed on: ago. 2019.

INSTITUTO NACIONAL DE PESQUISAS ESPACIAIS. Sistema de organização nacional de dados ambientais. Estações de medição de dados ambientais. Instituto Nacional de Pesquisas Espaciais. Available at: http://sonda.ccst.inpe. br/index.html. Accessed on: ago. 2019.

INTERNATIONAL ENERGY AGENCY. Energy Demand: Global Energy and CO2 Status Report 2018. Paris: International Energy Agency - IEA, 2018.

KALOGIROU, S. A. Solar Energy Engineering: processes and systems. 2. ed. [S.I.]: Elsevier, 2014. ISBN 978-0-12397270-5.

LIMA, G. C. d.; TOLEDO, A. L. L.; BOURIKAS, L. The role of national energy policies and life cycle emissions of pv systems in reducing global net emissions of greenhouse gases. Energies, v. 14, n. 4, 2021. ISSN 1996-1073. Available at:

https://www.mdpi.com/1996-1073/14/4/961. Acessed on: sep. 2020.

LUKAC, N. et al. Economic and environmental assessment of rooftops regarding suitability for photovoltaic systems installation based on remote sensing data. Energy,

v. 107 , p. $854-865,2016$.

MARTíN, A. M.; DOMíNGUEZ, J.; AMADOR, J. Applying lidar datasets and GIS based model to evaluate solar potential over roofs: a review. AIMS Energy, v. 3, n. 3, p. 326-343, 2015.

MATLAB. Version 7.10.0 (R2010a), Natick, Massachusetts: The MathWorks Inc. 2010.

NERO, M. A. et al. Case study of a model of local solar radiation potential and discussion on the associated sustainable applications and potentials. Sustainability in Debate, v. 11, n. 2, p. 173-189, 2020.

ONAT, N.; BAYAR, H. The sustainability indicators of power production systems. Renewable and Sustainable Energy Reviews, v. 14, p. 3108-3115, 2010.

PENG, J.; LU, L.; YANG, H. Review on life cycle assessment of energy payback and greenhouse gas emission of solar photovoltaic systems. Renewable and Sustainable Energy Reviews, v. 19, p. 255-274, 2013.

PEREIRA, E. B. et al. Atlas brasileiro de energia solar. São José dos Campos: Instituto Nacional de Pesquisas Espaciais (Inpe), 2017. ISBN 978-85-17-00089-8.

REN21. Renewables 2018 - Global Status Report. 2019.

SANTOS, T. et al. Applications of solar mapping in the urban environment. Applied Geography, v. 51, p. 48-57, 2014.

SANTOYO-CASTELAZO, E.; AZAPAGIC, A. Sustainability assessment of energy systems: integrating environmental, economic and social aspects. Journal of Cleaner Production, v. 80, p. 119-138, 2014. 
SÃO PAULO (estado). Anuário de energéticos por município no estado de São Paulo - 2018. Ano-base 2017. São Paulo: Secretaria de Energia e Mineração, 2018.

STEWART, J. Cálculo. 7. ed. São Paulo: Cengage Learning, 2015. ISBN 978-85-221-1259-3.

SUN, Y. et al. GIS-based approach for potential analysis of solar pv generation at the regional scale: a case study of Fujian province. Energy Policy, v. 58, p. 248-259, 2013.

TOLMASQUIM, M. T. Energia Renovável: hidráulica, biomassa, eólica, solar, oceânica. Rio de Janeiro: Empresa de Pesquisa Energética (EPE), 2016. ISBN 978-85-60025-06-0.

WILD-SCHOLTEN, M. J. Energy payback time and carbon footprint of commercial photovoltaic systems. Solar EnergyMaterials \& SolarCells, v. 119, p. 296-305, 2013.

WINTERLE, P. Vetores e geometria analítica. 2. ed. São Paulo: Pearson Education do Brasil, 2014. ISBN 978-85430-0239-2.

WU, P. et al. Review on life cycle assessment of energy payback of solar photovoltaic systems and a case study. Energy Procedia, v. 105, p. 68-74, 2017.

YUE, D.; YOU, F.; DARLING, S. B. Domestic and overseas manufacturing scenarios of silicon-based photovoltaics: life cycle energy and environmental comparative analysis. Solar Energy, v. 106, p. 669-678, 2014. 